Egypt. J. Aquat. Biol. \& Fish. Vol.10, No.2:93-116(2006) ISSN 1110-6131

\title{
A STUDY ON MOLECULAR BIOLOGY OF TILAPIA SPECIES AND THEIR HYBRIDS IN THE RIVER NILE, EGYPT.
}

\section{Sabry S. El-Serafy, Nassr-Allah H. Abdel-Hamide, Mohammed H. Awwad and Mona S. Azab}

Department of Zoology, Faculty of Science, Benha University, Benha, Egypt.

Key words: Tialpia, 18srDNA,RFLP, morphometric data, meristic, hybrids.

\section{ABSTRACT}

$\mathrm{M}$ orphometric, meristic and DNA ripoprinting analyses of Tilapia species and their hybrids inhabiting the River Nile were examined. The obtained morphometric data evoke striking similarities and overlapping among tilapia species. Accordingly it could not able to differentiate tilapia species. The obtained data of meristic characters reveal that tilapia species could be differentiated into four species (Oreochromis niloticus, $O$. auraeus, Sarotherodon galilaeus and Tilapia zillii). The lateral line scales differed significantly among the four-studied tilapia species. While the number of fin rays in the dorsal and anal fins differentiate significantly three Tilapia species (Confusion between $O$. niloticus and $O$. auraeus). Furthermore, the study used the technique of restriction fragment length polymorphism (RFLP) of nuclear small subunit ribosomal RNA (18SsrRNA) gene. The PCR-RFLP data provide a unique pattern for each examined species with a specific restriction enzyme. So, it could be possible to detect two hybrids of tilapia fish which are given $\mathrm{H} 1$ and $\mathrm{H} 2$ symbols. The endonucleases SacII and ApaI differentiate $\mathrm{H} 1$ and $\mathrm{H} 2$, respectively. Furthermore, the analyses of PCRRFLP data indicate that the $\mathrm{H} 1$ are closer to $O$. niloticus and $S$. galilaeus, whereas the $\mathrm{H} 2$ is phylogenetically closer to $O$. auraeus and $T$. zillii. The data of this research evoke a monophylogenetic relationship of all the studied Tilapia species. 
Sabry S. El-Serafy et al.

\section{INTRODUCTION}

Tilapia fish species represent the most important group of family Cichlidae. They constitute a major part of the fish fauna in the River Nile and its tributaries (Rajavarthini et al.,2000 ; Morals et al.,2001 ; Sharaf Eldeen and Abdel-Hamide,2002 ).So, they represent a valuable part of national income as they are characterized by delicious taste and cheap price. Furthermore, many researchers use it as a fish model to investigate different items (Abdel-Hamide, 1998;Yapi-Gnaore', 2001; Sharaf- Eldeen \& Abdel-Hamide, 2002; El-Serafy et al., 2003). Also, it is a successful model for aquaculture (Pullin, 1996). So, the need to characterize and to name tilapia is extremely needed (Pullin, 1996).Perdices et al.( 2005 ) considered that the application of molecular techniques would permit enhanced detection of evolutionary structure and taxonomy across the widespread species. They used the mitochondrial DNA to get evolutionary history of synbrachid eels. Burridge and Smolenski (2004) also used the sequencing of mitochondrial DNA to discriminate species of families Cheilodactlidae and Latridae and to show the biogeographical effect.

In the River Nile the reproduction between different tilapia species and the production of hybrids could be fulfilled. The differentiation of the hybrids could not be possible by using the morphological and meristic characters (Rajavarthini et al., 2000). Therefore, the present undertaken throw light on different classical fish identification and the molecular ( RFLP) method as well. This may help to identify the different hybrids of tilapia species.

\section{Studied fishes}

\section{MATERIALS AND METHODS}

Live tilapia fish species were collected from El-Riah ElTawfiqui (See El-Serafy et al., 2003).

\section{Morphometric characteristics}

For every fish the following measurements were done: total length ( $T L$ ), standard length ( SL), body depth ( $B D$ ), peduncle length ( PedL) ,predorsal fin length ( PrDFL), prepectoral fin length ( PrPectFL) ,prepelvic fin length( PrPelvFL), preanal fin length ( PrAnFL),Peduncle depth ( Ped D),Head length ( HL), head depth ( $\mathrm{HD}$ ), preorbital length (PrOL), eye diameter(ED), length of dorsal fin ( $L D F$ ), length of pectoral fin ( LpectF), length of pelvic fin (LpelvF) and length of anal fin (LanF) based on the method of Lagler et al. 
( 1977).These measurements were calculated according to the following formula:

Morphometric index $=$ Morphometric character/TL or HL $\times 100$ III. Meristic characteristics

The number of fin rays were counted in the dorsal fin (DFrs), in the anal fin (AnFrs) and in the caudal fin (CaudFrs ).Also, the number of lateral line scales (Lat.Lin.Scales) were counted from the end of the operculum to the end of the caudal peduncle. Fluctuating asymmetry (FA ) of the pectoral fin rays ,pelvic fin rays and gill rackers were done by counting the rays or the gill rackers of the right and left sides. Then FA was calculated by subtracting the right value from the left one ( Sanchez-Galan et al., 1997).

IV. DNA extraction

Genomic DNA of the studied tilapia species was extracted from the liver tissue following the method recommended by Hugo et al. (1992) and El-Serafy et al. (2003).

$V$. Determination and amplification of rDNA by polymerase chain reaction (PCR)

The standard PCR mixture was used according to Kessing et al.(1989).The entire nuclear srDNA was amplified using the primers SSU1[5'-CGACTGGTTGATCCTGCCAGTAG-3'] and SSU2 [3' TCCTGATCCTTCTAGGTTCAC-5 ' ] (Amresco ) anchored respectively in the conserved extremities of the 18SsrRNA gene (Stohard and Rollinson,1997).The detail of the standard PCR program for amplification of nuclear SsrRNA was recorded in El-Serafy et al.(2003).Nine restriction enzymes were used to differentiate tilapia species. These enzymes are $B g l$ land EcoRI (Amersham, Life Science),SacII, ApuI and Aval (Boehringer Mannheim) and SmaI, $A I w N I, X m a I$ and SstII (Sigma co. ,USA ) The detail of the gel preparation, running, sample loading and imaging was previously recorded in El-Serafy et al.(2003).

\section{Morphometric characteristics:}

\section{RESULTS}

According to the data in Table (1) the Standard Length / Total Length (SL/TL) ratio showed a significant differences when comparison made between Oreochromis aureus (O. auraeus) and Sarotherodon galilaeus (S. galilaeus) and Oreochromis niloticus (O. niloticus) and $(S$. galilaeus). While the differences between $S$. galilaeus and Tilapia zillii 
( T. zillii) are considered statistically more highly significant. But the difference is not significant between $O$. auraeus and $O$. niloticus, $O$. auraeus and $T$. zillii and $O$. niloticus and $T$. zillii.

Concerning the head length (HL/TL), its values change with highly significant differences between $O$. auraeus and S.galilaeus, $S$. galiaeus and $T$. zillii, $O$. niloticus and $T$. zillii. The difference between $O$. auraeus and $T$. zillii is considered more highly significant. Whereas, there is no significant changes between $O$. auraeus and $O$. niloticus and $O$. niloticus and $S$. galilaeus.

Regarding the body depth (BD/TL), the differences in its values are significant between O.niloticus and S.galilaeus and highly significant between $O$. auraeus and $T$. zillii. Whereas, the changes in BD/TL between $O$. niloticus and $T$. zillii, $O$. auraeus and S.galilaeus and $S$. galilaeus and $T$. zillii are statistically more highly significant. The differences between O.niloticus and O.auraeus are not significant .So, $O$. niloticus and O.auraeus are monophylogenetic species.

The values of predorsal fin indices (PrDFL /TL) when comparing between S.galilaeus and $T$. zillii are differed with a statistically more highly significant value. When comparing $O$. aureus and $O$. niloticus, $O$. aureus and S.galilaeus, $O$. aureus and $T$. zilli, $O$. niloticus and $S$. galilaeus and $O$. niloticus and $T$. zillii, the differences are considered not significant .So, tilapia species can be divided into three groups.

When comparing prepectoral fin length (PrPectFL /TL) of the examined tilapia species, the differences were found significant between $O$. aureus and $O$. niloticus and $O$. niloticus and $S$. galilaeus, and highly significant between $O$. niloticus and $T$. zillii. Whereas, the differences are more highly significant between $O$. aureus and S.galilaeus and $O$. aureus and $T$. zillii. But there is no significant difference between S.galilaeus and $T$. zillii.

Concerning prepelvic fin length as ratio of TL (PrPelvFL/TL), it changed with significant differences between $O$. niloticus and $T$. zillii, and with highly significant differences between $O$. aureus and $T$. zillii and $O$. niloticus and S.galilaeus. There is more highly significant difference in the value of PrPelvFL TL between $O$. aureus and $S$.galilaeus. But the changes between $O$. aureus and $O$. niloticus and $S$.galilaeus and $T$. zillii are statistically non-significant. So, these species are phylogenetically related ones.

Regarding the preanal fin length (PrAnFL /TL), there are highly significant differences in its values when comparing between $O$. aureus 
and $O$. niloticus and more highly significant differences were found between $O$. niloticus and S.galilaeus and $O$. niloticus and T. zillii. Whereas, the differences are not significant between $O$. aureus and S.galilaeus, O. aureus and T. zillii and S.galilaeus and T. zillii.

Concerning the length of the dorsal fin as a part of TL (LDF/TL), significant differences were found between $O$. auraeus and $O$. niloticus and $O$. niloticus and S.galilaeus. Whereas, the differences between $O$. niloticus and $T$. zillii, $O$. auraeus and S.galilaeus, $O$. auraeus and $T$. zillii and S.galilaeus and T. zillii were found to be not significant.

When comparing the ratio of the length of the pectoral fin related to TL (LpectF / TL), the differences between $O$. auraeus and T. zilli, $O$. niloticus and $T$. zillii and S.galilaeus and $T$. zillii were considered statistically more highly significant, while between $O$. auraeus and $d O$. niloticus, $O$. auraeus and S.galilaeus and O. niloticus and S.galilaeus were not significant.

Regarding the length of the pelvic fin as a ratio of TL (LpelvF /TL), the difference is significant between $O$. auraeus and S.galilaeus, while differences between $O$. auraeus and $T$. zillii is more highly significant . The differences in the LpelvF/TL values are not significant between $O$. auraeus and $O$. niloticus, $O$. niloticus and S.galilaeus, O. niloticus and T. zillii and S.galilaeus and T. zillii.

The length of anal fin as a ratio of TL (LanF/TL), changed with significant differences between $O$. auraeus and $O$. niloticus and $O$. auraeus and S.galilaeus, and with highly significant differences between $O$. auraeus and T. zillii. But there are no significant changes between $O$. niloticus and S.galilaeus, $O$. niloticus and T. zilli and S.galilaeus and $T$. zillii.

Concerning the peduncle length divided by TL (PedL/TL), the differences in its values between each of $O$. auraeus and $T$. zillii, $O$. niloticus and $T$. zillii and S.galilaeus and $T$. zillii are considered statistically more highly significant. But there are no significant changes between $O$. auraeus and $O$. niloticus, $O$. auraeus and S.galilaeus and $O$. niloticus and S.galilaeus.

Peduncle depth ( PedD /TL) of tilapia species varies with more highly significant differences between $O$. auraeus and S.galilaeus, $O$. niloticus and S.galilaeus and S.galilaeus and T. zillii. Whereas, the difference between $O$. auraeus and $O$. niloticus, $O$. auraeus and $T$. zillii and $O$. niloticus and $T$. zillii are statistically not significant. 
The preocular length related to $\mathrm{HL}$ (PrOL/HL), the differences between $O$. auraeus and $T$. zillii , O. niloticus and $T$. zillii and S.galilaeus and T.zillii are found statistically more highly significant. But the differences between O.auraeus and O.niloticus, O.auraeus and S.galilaeus and $O$.niloticus and S.galilaeus are considered not significant.

When comparing eye diameter as a ratio of $\mathrm{HL}$ (ED/HL), the differences are highly significant between $O$. auraeus and $O$. niloticus and O.auraeus and S.galilaeus, while the more highly significant differences were found between O.auraeus and T.zillii, but there is no significant differences between $O$. niloticus and S.galilaeus, $O$. niloticus and T.zilli and S.galilaeus and T. zillii.

The data of head depth related to HL (HD/HL) show a significant difference between S.galilaeus and T.zillii. Whereas, when the comparison made between O.auraeus and T.zillii and O.niloticus and S.galilaeus the differences were highly significant. A more highly significant difference was found between $O$. auraeus and S.galilaeus. There are no significant differences between O.aurcreus and O.niloticus and O.niloticus and T.zillii.

The head depth as a ratio of head length ( HD/ HL)differed significantly between S.galilaeus and T.zillii. Highly significant differences were found between $O$. auraeus and T.zillii, $O$. auraeus and S.galilaeus and O.niloticus and S.galilaeus. No significant differences were recorded when the comparison was made among $O$. niloticus, $O$. auraeus and T. zillii.

\section{II.Meristic characteristics}

Seven meristic characteristics were selected in this study. The available data are tabulated in Tables ( 3,4 and 5$)$. The number of dorsal fin rays (DFrs) differed significantly when comparing S.galilaeus and $O$. auraeus , O. niloticus and S.galilaeus, $O$. auraeus and T.zillii, $O$. niloticus and $T$. zillii and S.galilaeus and $T$. zillii. But no significant difference was found between $O$. auraeus and $O$. niloticus. So, DFrs differentiate tialpia species except $O$. auraeus and $O$. niloticus. This is an indication of the same origin for both species.

The fin rays of anal fin (AnFrs) varied with more highly significant differences when the comparison was made between all tilapia species except between $O$. auraeus and $O$. niloticus.

When comparing the number of caudai fin rays (CaudFrs) a significant differences were found between $O$. niloticus and $T$. zillii, $O$. auraeus and O.niloticus and $O$. niloticus and $S$. galilaeus. No significant 
differences between the rest of the compared group. The number of scales in the lateral line (Lat.Lin.scales) differed significantly between all the studied tilapia species.

Fluctuating asymmetry (FA) of the pectoral, pelvic fins and the gill rackers were presented in Table ( 5 ) The obtained data show a fluctuation between the right and the left sides in the number of pectoral fin rays (PectFrs) in all tilapia species except $S$.galilaeus. The pelvic fin rays ( PelvFrs) of all tilapia species are bilaterally identical $(\mathrm{FA}=0$ ) .Whereas, the FA of the gill rackers (GRs) are highly represented in all tilapia species.

The data recorded in Table ( 2 ) show a high similarity coefficient (0.69) when comparing the morphometric characteristics between $O$. niloticus and $O$. amaeus, whereas the values of similarity coefficient are less than $50 \%$ when comparing the rest of tilapia species. This indicates that O.niloticus and O. auraeus are closely similar in their morphological characters. Furthermore, the degree of similarity between $O$. niloticus and $O$. aurcieus reaches to 0.5 in its meristic characters in general indicating that these two species are close together (Table, 4 ). Zero similarity coefficient was recorded when comparing $O$. niloticus and S.galilaeus and $O$. niloticus and T.zillii. Also, a very low similarity coefficient was reported when comparing the meristic characters between $O$. auraeus and $S$. galilaeus, $O$. auraeus and $T$. zillii and S.galilaeus and $T$. zillii indicating that these three species display great degree of differences.

\section{RFLP of 18SsrRNA gene}

The polymerase chain reaction-restriction fragment length polymorphism (PCR-RFLP) technique was used to identify the various tilapia species in the River Nile (El-Serafy et al., 2003). Figure (1) represents the separation of tilapia DNA genome, which appear in a smear like form as it has a high molecular weight. But the $1 \mathrm{~kb}$ DNA ladder represented in the first lane was separated into bands with different lengths. The PCR products of 18 SsrRNA gene for tilapia species appeared at a length $\sim 2000$ bp (Fig. 2).

There are some restriction endonucleases (EcoRI and BgII; Figs. 3 and 4) did not differentiate between the different strains of tilapia species. EcoRI restriction enzyme collected the species in one cluster when fragmented their rRNA gene into two cuts $(\sim 1650$ and $\sim 350 \mathrm{bp}$; Fig. 3). The gene of all species was cut into two fragments $(-1250$ and $\sim 750$ bp; Fig. 4) when digested with $B g 11$ restriction endonuclease. 
The restriction enzyme, SmaI, cut the studied gene of one species only ( $T$. zillii )into two fragments $(\sim 1250 \& \sim 950 \mathrm{bp})$. While the rest of tilapia species genes were not fragmented and separated parallel to 2000 bp of DNA ladder (Fig. 5). So, it differentiates $T$. zillii from the rest of tilapia species.

The 18SsrRNA gene of $O$. niloticus was digested into two distinct bands $(\sim 1750$ bp \& $\sim 300$ bp) by using the enzyme AlwNI (Fig. $6)$. Whereas, the gene was not splitted in the rest of tilapia species. Only $O$. auraeus 18SsrRNA gene was digested by the enzyme XmaI producing two fragments at lengths $\sim 1100 \mathrm{bp}$ and $\sim 900 \mathrm{bp}$ (Fig. 7). The gene pattern in the other species is identical. So, the prescribed endonucleases differentiate $O$. niloticus and $O$. auraeus from the other tilapia species.

Three restricted fragments $(\sim 1000 \mathrm{bp}, \sim 650 \mathrm{bp} \& \sim 350 \mathrm{bp})$ belonging to $T$. zillii, $O$. niloticus, $O$. auraeus, S.galilaeus and $\mathrm{H} 2$ produced after digestion with the enzyme SacII ( Fig.9). The enzyme cuts the examined gene of $\mathrm{H} 1$ into two fiagments which appeared at $\sim 1650 \mathrm{bp}$ and $\sim 350 \mathrm{bp}$. For this reason the H1 could be detected by testing the PCR product of 18srRNA gene after digestion with the enzyme SacII .

Enzyme Apal cuts the undertaken genes of $T$. zillii, $O$. niloticus, $O$. auraeus , $S$. galilaeus and $\mathrm{Hl}$ into three bands with lengths $\sim 950 \mathrm{bp}, \sim 800 \mathrm{bp}$ and $\sim 250 \mathrm{bp}$ (Fig. 10). Whereas, only two bands were reported for species $\mathrm{H} 2(\sim 1200$ bp and $\sim 800 \mathrm{bp})$. So, by using the enzyme ApaI ,H2 can be separated from tilapia species inhabiting the River Nile in the Egyptian waters.

Tilapia species and their hybrids ( $\mathrm{Hl}$ and $\mathrm{H} 2$ ) were separated into three distinct groups according to the results of 18srRNA-gene digestion with the enzyme Aval. The first group includes $T$. zillii, $O$. auraeus and $S$. galilaeus in which five distinct bands ( $\sim 00 \mathrm{bp}, \sim 550 \mathrm{bp}$, $\sim 300 \mathrm{bp}, \sim 250 \mathrm{bp}$ and $\sim 200 \mathrm{bp}$ ) appeared after digestion (Fig., 11). The second group is represented only by $O$. niloticus in which six restricted fragments were separated with base pairs of $\sim 650, \sim 500, \sim 350$, $\sim 250, \sim 150$ and $\sim 100$.Tilapia hybrids ( $\mathrm{Hl}$ and $\mathrm{H} 2$ ) constitute the third group, where four distinct fragments were with lengths $\sim 800$ $\mathrm{bp}, \sim 700 \mathrm{bp}, \sim 300 \mathrm{bp}$ and $\sim 200 \mathrm{bp}$. So, this enzyme is not species specific and could partially differentiate tilapia fish. 


\section{DISCUSSION}

The species identification of fish species including tilapia depends on the first step for morphometric and Meristic characters of the body parts (Yapi-Gnaore, 2001). The morphological identification of tilapia species is so complicated by the extensive intraspecific variations of the morphometric measurements used for quick species identification (Albertson et al., 1999). The results of the present work indicate a great morphological identity between the three tilapia genera Oreochromis, Sarotherodon and Tilapia. Regarding the data of morphometric and meristic characters, two species are very closely related; these are $O$. niloticus and $O$. auraeus. Suggesting that they are monophyltic species (derived from the same genus). This phenomenon was previously reported by Oberst et al. ( 1996 ). They morphologically differentiated three species of genus tilapia ( $T$. dageti, $T$. zillii and $T$. guineensis) indicating striking similarities ,so they are monophyltic species. This agrees with the work of El-Serafy et al. (2003) on the same species inhabiting the River Nile.

Lovshin (1982) found that the systematic distance between the species is the main reason for reproductive behaviour barrier. In the present study the monophylogenetic relationship between the genus Oreochromis and the genus Sarotherodon are recorded. They are both mouth brooding species. For this reason natural hybridization between them is possible with a concomitant propagation of tilapia hybrids in the River Nile habitat. The analysis of morphometric and merisitic characteristics can differentiate species but not strains or hybrids (Pante et al., 1988). By comparing the PCR-RFLP product of specific endonucleases activity with the gene of $\mathrm{H} 1$ and $\mathrm{H} 2$ with those of the rest of tilapia species. It was found that in case of $\mathrm{Hl}$ the length cut is $~ 350$ and $\sim 1650 \mathrm{bp}$. The closer species of $\mathrm{Hl}$ regarding the length of bp cut is $O$. niloticus and $S$. galilaeus. On the other hand, the length of gene cut of $\mathrm{H} 2$ by specific enzyme is $\sim 1200 \mathrm{bp}$ and $\sim 800 \mathrm{bp}$.According to the length of bp cut ,T. zillii and $O$. curaeus are closer with $\mathrm{H} 2$. Whereas, the obtained results indicate a lesser degree of similarity between genus Tilapia and the other two genera showing a polyphyltic species. This phenomenon was recorded previously in case of synbranchid eel genera in different habitat ( Perdices et al ., 2005).

Furthermore, the data of FA of the gill rackers discriminate tilapia species into three groups that present confusion between $O$. niloticus and $O$. auraeus and a higher degree of similarity between $O$. 
aurcaeus and S.galilaeus. The observed data differentiate $T$. zillii as a separate group with less degree of similarity. Thus, according to the data of FA tilapia species can be sorted into three groups. This result coincides with the results of Falk el al. (1996) and Oberst et al. (1996).

Rognone and guyomard (2003) states that the morphological parameters of fishes are influenced by both genetic and environmental factors.

For this reason the molecular techniques data based on PCRRFLP analysis of the 18SsrRNA gene have been extensively used as a precise tool of species identity of fishes (Fernandez, 2001; El-Serafy et al., 2003 and Perdices et al., 2005). Farias et al. (1999) and El-Serafy et al. (2003) used the RFLP -PCR products of nuclear and mitochondrial DNA as a tool to identify Tilapia species. The results obtained indicate that the rstriction enzyme Smal differentiate all species as one group except for $T$. zillii, this confirmed the monophylogenetic relationships of all species except $T$. zillii which displays a polyphylogenetic relationship.

By using the endonuclease SacIl the RFLP profile discriminates H1 from the rest of the examined species, so this enzyme is a specific for $\mathrm{H} 1$ gene and it could be possible to used for $\mathrm{H} 1$ identification.On the other hand, the data obtained after using the endonuclease ApaI are characteristic for $\mathrm{H} 2$ gene. The RFLP data discriminate $\mathrm{H} 2$ from the rest of tilapia species, so it could be a useful tool to identify $\mathrm{H} 2$ fish species.

All studied species may be differentiated into three groups when using the enzyme Aval: group (1) include $T$. zillii, $O$. auraeus and $S$. galialeus, group (2) include $\mathrm{H} 1$, and $\mathrm{H} 2$ and group include $O$. niloticus. These results suggest that this endonuclease can be used to identify hybrids.. Sequencing PCR fragments has become a standard technique in laboratories applying recombinant DNA technologies. Several authors declaired that the RFLP option is simpler and faster in addition to its less cost (Ran et al., 1996; Cespedes et al., 1998 ; Quinteiro et al., 1998).

\section{Conclusion}

The present study shows that the use of the PCR - RFLP profile is a simple and rapid method for the detection of tilapia hybrids, which may be important for fish farming, and research protocols. The degree of genetic relation was found between $\mathrm{Hl}$ and $O$. niloticus and S.galilaeus, whereas $\mathrm{H} 2$ is genetically related to $T$. zillii and $O$. niloticus. 
A STUDY ON MOLECULAR BIOLOGY OF TILAPIA 103 SPECIES AND THEIR HYBRIDS IN THE RIVER NILE.

\section{REFERENCES}

Abdel-Hamide, N. A.H.( 1998 ). Biology of reproduction of Oreochromis niloticus (Linnaeus, 1758 ). Ph.D. thesis, Fac. Sci., Zagazig Univ., Benha Branch, 206 pp.

Alberston, R.C.; Market, J. A.; Danley, P. D. and Kocher, T.D. ( 1999 ).Phylogny of a rapidly evolving clade : The cichlid fishes of Lake Malawi ,East Africa .Proc.Natl.Acad.Sci.,USA,96 :51075110.

Burridge, C. P. and Smolenski, A. J. (2004). Molecular phylogeny of the Cheilodactylidae and Latridae (Perciformes: Cirrhitoidea) with notes on taxonomy and biogeography. Molecular Phylogenetic and Evoultion ,30 (1):118-127.

Cespedes, A.; Garcia, T.; Carrera , E.; Gonzalez, I. ; Sanz , B. ; Hernandez, P. E. and Martin, R. ( 1998 ). Identification of flatfish species using polymerase chain reaction ( $\mathrm{PCR}$ ) :Amplification and restriction analysis of the cytochrome b gene. J. Food Sci., $63: 2$.

El-Serafy, S. S.; Awwad, M.H.; Abdel -Hamide, N. A. H. and Azab, M. S. ( 2003 ). Restriction fragment length polymorphism's ( RFLPs ) of the small subunit ribosomal DNA as a tool for identification of tilapia spp. Egypt .J. Aquat. Biol. \& Fish., 4 :465482.

Falk, T. M. ; Abban, E.K. ; Oberst, S.; Villwock, W. ; Pullin, R. S. V. and Rewrantz, L. ( 1996 ). A biochemical laboratory manual for species characterization of some tilapiine fishes .ICLARM Educ.Ser.,17:93pp.

Faris, I. P. ;Orti , G. ; Sampaio, I. ; Schneider „H. and Meyer , A. (1999).Miochondrial DNA phylogeny of the family Cichlidae :monophyly and fast molecular evolution of the Neotropical assemblage .J. Mol.Evol.,48 :703-711.

Fernandez, A. ; Garcia ,T. ; Asensio , L. Bodreguez, M. A.;Gonzalez ,L.; Hernandez, P. E. and Martin, R. ( 2001 ). PCR-RFLP analysis of 
the internal transcribed spacer (ITS) Region for identification of 3 clam species.J. Food Sci., 66:5.

Hugo , E. R. ; Stewart, V. J. ; Gast, R.J. and Byers, T. J. ( 1992 ). Purification of amoeba mtDNA using the unset procedure In "protocols in protozology, “ J. J. Lee \& A. T. Soldo, eds. Protozoologists, Lawrence, kA. D7.1-7.2.

Kessing, B.; Croom, H.; Martin, A.; McIntosh, C. ; McMillan ,W.O. and Palumbi , S. ( 1989 ). The simple fool's guide to PCR ( S. Palumbi and C. Simon lab manual).

Lagler, K. E.; Bardach, J. E.; Miller, R. and Passino, D.R.M. (1977). Ichthyology. John Wiley and Sons, Inc., New York.

Lovshin , L.L. ( 1982 ). Tilapia hybridization .pp.279-308.In R.S.V. Pullin and R. H. Lowe-McConnell, eds. The Biology and culture of Tilapias. ICLARM Con.Proc., 7.Manilla ,Philippines .

Morals, R.; Herrera, M. T. ;Arenal ,A.; Cruz , A. ;Hernặndez ,O.: Pimentel , R .; Guillçn,l.; Martinez, R. and Estrada, M.P. ( 2001 ). Tilapia chromosomal hormone gene expression accelerates growth in transgenic zebrafish ( Danio rerio) . Elect. J. Biotech., ISSN: $0717-3458,4: 2$.

Oberst, S.; Abban ,E. K. and Villwock, W. ( 1996 ). Biochemical and immunological markers for discrimination of three tilapia species :T. zillii Gervais ,T. guineensis Bleeker and T.dageti Thys v.d. Audenaerde ( Pisces : Cichlidae) from West Africa.Aquacul.Res., 27: 235-244 .

Pante, M. J. R.; Lester, L.J. and Pullin ,R .S.V. ( 1998 ). A preliminary study on the use of canonical discriminate analysis of morphometric and Meristic characters to identify cultured tilapia, In " R. S. V. Pullin, T. Bhukaswan, K. Tonguthal and J. L.Maclean.

Perdices, A ; Doadrio ,I.; and Bermingham, E. ( 2005 ). Evolutionary history of the synbranchid eels (Teleostei : Synbranchidae) in central America and the Caribbean islands inferred from their 
molecular phylogeny .Molecular Phylogenetics and Evolution $.37: 460-473$.

Pullin, R. S. V. (1996). World tilaipa culture and its future prospects .In R.S.V. Pullin, J. Lazard, M. Legendre,J.B. Amon Kothias and D. Pauly (eds. ). The Third International Symbosium on Tilapia in Aquaculture: ICLARM Conf.Proc., $41 \mathrm{pp}$.

Quinteiro. J.; Sotelo, C. G.: Rehbein, H. ;Pryde ,S. E. ;Medina, I . ( 1998 ).Use of mtDNA direct polymerase chain reaction ( PCR) sequencing and PCR-restriction fragment length polymorphism methodologies in species identification of canned tuna ..J. Agric. Food Chen.,46:1662-1669.

Rajavarthini, P .B.; Arunkumar , R. I. and Michael ,R. D. ( 2000 ).Partial characterization of serum immunoglobulins of Oreochromis mossambicus .Ind. J. Exp. Biol., 38 (6):549-553.

Ram, J.L.; Ram, M. L. and Baidoum , F.F. ( 1996 ). Authentication of canned tuna and bonito by sequence and restriction site analysis of polymerase chain reaction products of mitochondrial DNA. J. Agric. Food Chem.,44: 2460- 2467.

Rognon, X. and Guyomard ,R. ( 2003 ). Large extent of mitochondrial DNA transfer from Oreochromis auraeus to Orechromis niloticus in West Africa. Mol. Ecol., 12 (2):435.

Sânchez -Galân , S.; Linde , A. R. ; Izquierdo , J.I. and Garcia-vazquez, E. ( 1997 ). Micronuclei and fluctuating asymmetry in brown trout

( Salmo trutta) :complementary methods to biomonitor fresh water ecosystems.Mut.Res.,412:219-255.

Sharaf-Eldeen, K. and Abdel-Hamide, N.( 2002 ). Sublethal effect of copper sulphate, malathion and paraquat on protein pattern of Oreochromis niloticus. Egypt. J. Aqua. Biol. \& Fish. ,6 (2) : 167182.

Stothard, G. R. and Rollinson , D.( 1997 ). Molecular characterization of Bullinus globosus and B.nasutus in Zanzibar and an investigation 
of their roles in the epidemiology of Schistosoma haematobium Trans.R.Soc.Trop.Med.Hyg.,91:353-357.

Yapi-Gnaore,V.( 2001 ). Fish genetics research in Cote dilvoire.In M.V. Gupta and B.O. Acosta (eds. ), pp 25-28. 
Table (1): Morphometric indices (Average \pm SE) of different tilapia species.

1- In Total Length :

\begin{tabular}{|l|c|c|c|c|c|c|c|c|}
\hline \multirow{2}{*}{ Morphometric ratio } & \multicolumn{2}{|c|}{ O. niloticus } & \multicolumn{2}{c|}{ O. oureus } & \multicolumn{2}{c|}{ S. galilaeus } & \multicolumn{2}{c|}{ T. zillii } \\
\cline { 2 - 8 } & Mean & SE & Mean & SE & Mean & SE & Mean & SE \\
\hline SL/TL & 81.55 & \pm 0.25 & 81.45 & \pm 0.26 & 80.32 & \pm 0.37 & 82.41 & \pm 0.41 \\
\hline HL/TL & 25.53 & \pm 0.32 & 25.80 & \pm 0.20 & 25.08 & \pm 0.16 & 23.94 & \pm 0.30 \\
\hline BD/TL & 36.04 & \pm 0.48 & 35.15 & \pm 0.37 & 37.59 & \pm 0.30 & 33.23 & \pm 0.40 \\
\hline PrDFL/TL & 27.09 & \pm 0.50 & 27.24 & \pm 0.48 & 26.53 & \pm 0.21 & 28.03 & \pm 0.34 \\
\hline PrPectFL/TL & 29.26 & \pm 0.30 & 30.31 & \pm 0.23 & 28.22 & \pm 0.37 & 27.89 & \pm 0.29 \\
\hline PrPelvFL/TL & 34.11 & \pm 0.50 & 34.29 & \pm 0.36 & 32.49 & \pm 0.30 & 32.33 & \pm 0.42 \\
\hline PrAnFL/TL & 59.64 & \pm 0.20 & 58.68 & \pm 0.23 & 57.82 & \pm 0.43 & 58.02 & \pm 0.36 \\
\hline LDF/TL & 51.88 & \pm 1.22 & 48.87 & \pm 0.22 & 48.47 & \pm 0.73 & 48.80 & \pm 1.30 \\
\hline LpectF/TL & 26.43 & \pm 0.51 & 27.0 & \pm 0.32 & 26.78 & \pm 0.88 & 21.38 & \pm 0.42 \\
\hline LpelvF/TL & 18.31 & \pm 0.53 & 19.40 & \pm 0.13 & 18.33 & \pm 0.41 & 17.64 & \pm 0.38 \\
\hline LAnF/TL & 17.76 & \pm 1.16 & 14.51 & \pm 0.20 & 16.09 & \pm 0.58 & 18.74 & \pm 1.23 \\
\hline PedL/TL & 10.52 & \pm 0.24 & 10.94 & \pm 0.28 & 10.34 & \pm 0.25 & 13.88 & \pm 0.12 \\
\hline PedD/TL & 13.02 & \pm 0.22 & 12.81 & \pm 0.17 & 14.54 & \pm 0.16 & 12.45 & \pm 0.35 \\
\hline
\end{tabular}

2-In head length:

\begin{tabular}{|l|c|c|c|c|c|c|c|c|}
\hline \multirow{2}{*}{$\begin{array}{c}\text { Morphometric } \\
\text { ratio }\end{array}$} & \multicolumn{2}{|c|}{ O. niloticus } & \multicolumn{2}{c|}{ O. oureus } & \multicolumn{2}{c|}{ S. galilaeus } & \multicolumn{2}{c|}{ T. zillii } \\
\cline { 2 - 8 } & Mean & SE & Mean & SE & Mean & SE & Mean & SE \\
\hline PrOL/HL & 31.24 & \pm 0.51 & 30.78 & \pm 0.68 & 31.50 & \pm 0.52 & 35.24 & \pm 0.66 \\
\hline $\mathrm{ED} / \mathrm{HL}$ & 29.54 & \pm 0.44 & 27.58 & \pm 0.37 & 29.16 & \pm 0.38 & 30.10 & \pm 0.45 \\
\hline $\mathrm{HD} / \mathrm{HL}$ & 111.49 & \pm 2.59 & 110.29 & \pm 1.46 & 121.35 & \pm 1.30 & 116.16 & \pm 1.53 \\
\hline
\end{tabular}


Sabry S. El-Serafy et al.

Tabie (2): The significance (t-test) among different morphometric indices of different tilapia species:

1- In total length :

\begin{tabular}{|c|c|c|c|c|c|c|}
\hline $\begin{array}{l}\text { Morphometr } \\
\text { ic ratio }\end{array}$ & $0.11 \times 0.11 u$ & $0.11 \times S . g$ & $0 . n \times T .:$ & $0 . a n \times S . y$ & $0 . a 11 \times T .2$ & $S . g \times T_{. z}$ \\
\hline SL/TL & 0.2794 & $2.7437^{*}$ & 1.8048 & $2.5019 *$ & 2.0031 & $3.7995^{* * *}$ \\
\hline HL/TL & 0.7221 & 1.2736 & $3.6580^{* * *}$ & $2.7986^{* *}$ & $5.1534^{* * *}$ & $3.3568^{* *}$ \\
\hline $\mathrm{BD} / \mathrm{TL}$ & 1.4791 & $2.7531^{*}$ & $4.5478^{* * *}$ & $5.1147^{* * 4}$ & $3.5507^{* *}$ & $8.7671^{* * *}$ \\
\hline PrDFL/TL & 0.2179 & 1.0361 & 1.5608 & 1.3677 & 1.3546 & $3.7719^{* * *}$ \\
\hline$\overline{\text { PrPectFl/TL }}$ & $2,7290^{*}$ & $2,1545^{*}$ & $3.2752^{* *}$ & $4.7284^{* * *}$ & $6.5299^{* * *}$ & 0.6999 \\
\hline PrPelvFL/TL & 0.2926 & $2.7840^{*}$ & $2.7442^{*}$ & $3.7916 * * *$ & $3.5345^{* *}$ & 0.3092 \\
\hline PIARFLTL & $3.1418^{* *}$ & $3.8622^{* * *}$ & $3.8937^{* * *}$ & 1.7767 & 1.5330 & 0.3569 \\
\hline LDF/TL & $2.4366^{*}$ & $2.4057^{k}$ & 1.7310 & 0.5264 & 0.0532 & 0.2216 \\
\hline LPeciF/TL & 0.9493 & 0.3453 & $7.6263^{* * *}$ & 0.2365 & $10.9607^{* * *}$ & $5.5600 * * *$ \\
\hline LPelvF/TL & 1.9802 & 0.0296 & 1.0174 & $2.4677^{*}$ & $4.3282^{* * *}$ & 1.2223 \\
\hline LAnF/TL & $2.7580^{*}$ & 1.2844 & 0.5782 & $2.5665^{*}$ & $3.3849^{* *}$ & 1.9411 \\
\hline PedL/TL & 1.1526 & 0.5186 & $12.7062^{* * *}$ & 1.6015 & $9.8094 * * *$ & $12.7139^{* * *}$ \\
\hline PedDTL & 0.9966 & $7.4327^{* * *}$ & 1.5307 & $7.3434^{* * *}$ & 0.9223 & $5.4005^{* * *}$ \\
\hline
\end{tabular}

2- In head length:

\begin{tabular}{|l|l|l|l|l|l|l|}
\hline $\begin{array}{l}\text { Morphometric } \\
\text { ratio }\end{array}$ & $\begin{array}{l}0 . n \times \\
0 . n u\end{array}$ & $0 . n \times S . g$ & $0 . n \times S . g$ & $\begin{array}{l}\text { O.nu } \\
T . z\end{array}$ & $0 . n u \times T . z$ & $S . g \times T . z$ \\
\hline PrOL/HL & 0.5375 & 0.8399 & 0.3569 & $4.7895^{* * *}$ & $4.6968^{* * *}$ & $4.4696^{* * *}$ \\
\hline ED/HL & $3.4189^{* *}$ & $2.9841^{* *}$ & 0.6589 & 0.8915 & $4.3066^{* * *}$ & 1.5974 \\
\hline HD/HL & 0.4042 & $5.6582^{* * *}$ & $3.4033^{* *}$ & 1.5547 & $2.7829^{* *}$ & 2.5857 \\
\hline $\begin{array}{l}\text { Similarity } \\
\text { coefficient }\end{array}$ & 0.69 & 0.44 & 0.5 & 0.44 & 0.31 & 0.44 \\
\hline
\end{tabular}

Number of tested fishes $=15$

* Significant at $P<0.05$

* * Significant at $P<0.01$

*** Significant at $P<0.001$
O.n.: Orechromis niloticus

0 . au.: Oreochromis aurets

S.g.: Sarotherodon galilaeus

T.z.: Tilapia zillii 
A STUDY ON MOLECULAR BIOLOGY OF TILAPIA 109 SPECIES AND THEIR HYBRIDS IN THE RIVER NILE.

Table (3) Meristic characteristics (Mean \pm SE) of different tilapia species.

\begin{tabular}{|c|c|c|c|c|c|c|c|c|}
\hline \multirow{2}{*}{ Meristic Count } & \multicolumn{2}{|c|}{ O. niloticus } & \multicolumn{2}{|c|}{ O. oureus } & \multicolumn{2}{|c|}{ S. galilaeus } & \multicolumn{2}{|c|}{ T. zillii } \\
\hline & Mean & $\mathrm{SE}$ & Mean & SE & Mean & SE & Mean & SE \\
\hline DFrs & 29.57 & \pm 0.13 & 29.65 & \pm 0.12 & 28.95 & $\begin{array}{l} \pm 0.1 \\
7\end{array}$ & 27.0 & $\begin{array}{l} \pm 0.0 \\
8\end{array}$ \\
\hline AnFrs & 12.07 & \pm 012 & 12.35 & \pm 015 & 14.05 & $\begin{array}{l} \pm 0.2 \\
0 \\
\end{array}$ & 11.35 & $\begin{array}{l} \pm 0.1 \\
5 \\
\end{array}$ \\
\hline CaudFrs & 16.79 & $\pm 0 . \hat{l}$ & 16.25 & \pm 0.11 & 16.05 & $\begin{array}{l} \pm 0.1 \\
0\end{array}$ & 16.30 & $\begin{array}{l} \pm 0.1 \\
4\end{array}$ \\
\hline Lat.Lin. Scales & 33.11 & \pm 0.15 & 33.65 & \pm 0.20 & 32.24 & $\begin{array}{l} \pm 0.1 \\
5\end{array}$ & 31.0 & $\begin{array}{l} \pm 0.2 \\
7\end{array}$ \\
\hline
\end{tabular}

Table (4) : The significance (t-test) among different meristic characteristics of different tilapia species.

\begin{tabular}{|l|l|l|l|l|l|l|}
\hline Meristic Count & $\begin{array}{l}\text { O.n } \\
\times 0 . a u\end{array}$ & $0 . n \times S . g$ & $0 . n \times T . z$ & $0 . a t 1 \times S . g$ & $0 . a u \times T . z$ & $S . g \times T . z$ \\
\hline DFrs & $0.4516 \cdot$ & $2.9443^{* *}$ & $17.1664^{* * *}$ & $3.3552^{* *}$ & $17.9618^{* * *}$ & $10.4873^{* * *}$ \\
\hline AnFrs & 1.4805 & $8.3885^{* * *}$ & $3.8070^{* * *}$ & $6.7586^{* * *}$ & $4.8045^{* * *}$ & $10.7343^{* * *}$ \\
\hline CaudFrs & $3.5200^{* *}$ & $5.1269^{* * *}$ & $2.7343^{*}$ & 1.3498 & 0.2743 & 1.4307 \\
\hline Lat.Lin. Scales & $2.1468^{*}$ & $3.5769^{* *}$ & $6.8399^{* * *}$ & $5.0123^{* * *}$ & $7.8108^{* * *}$ & $3.7218^{* * *}$ \\
\hline $\begin{array}{l}\text { Similarity' } \\
\text { coefficient }\end{array}$ & 0.5 & 0.0 & 0.0 & 0.25 & 0.25 & 0.25 \\
\hline
\end{tabular}


Sabry S. El-Serafy et al.

Table (5) Fluctuating asymmetry (FA) of different tilapia species.

\begin{tabular}{|c|c|c|c|c|c|c|c|c|c|c|c|c|c|}
\hline \multirow{2}{*}{\multicolumn{2}{|c|}{ Species }} & \multicolumn{4}{|c|}{ Pectroal Fin Rays } & \multicolumn{4}{|c|}{ Pelvic Iin Rays } & \multicolumn{4}{|c|}{ Gill Rackers } \\
\hline & & Right & Left & FA & $\begin{array}{c}\% \mathrm{~F} \\
\mathrm{~A}\end{array}$ & Right & Left & FA & $\% F A$ & Right & Left & FA & $\% \mathrm{~F}$ \\
\hline O.nilloricus & $\begin{array}{l}\text { Mean } \\
\pm S E\end{array}$ & $\begin{array}{l}13.36 \\
0.19\end{array}$ & $\begin{array}{l}13.50 \\
0.13\end{array}$ & $\begin{array}{l}0.14 \\
0.09\end{array}$ & $\begin{array}{l}13.3 \\
\%\end{array}$ & $\begin{array}{l}6.0 \\
0.0\end{array}$ & $\begin{array}{l}6.0 \\
0.0\end{array}$ & $\begin{array}{l}0.0 \\
0.0\end{array}$ & $0.0 \%$ & $\begin{array}{l}30.50 \\
0.45\end{array}$ & $\begin{array}{l}30.21 \\
0.34\end{array}$ & $\begin{array}{l}1.29 \\
0.32\end{array}$ & $60 \%$ \\
\hline O. anreus & $\begin{array}{l}\text { Mean } \\
\pm S E\end{array}$ & $\begin{array}{l}13.7 \\
0.12\end{array}$ & $\begin{array}{l}13.7 \\
0.12\end{array}$ & $\begin{array}{l}0.10 \\
0.08\end{array}$ & $\begin{array}{l}13.3 \\
\%\end{array}$ & $\begin{array}{l}6.0 \\
0.0\end{array}$ & $\begin{array}{l}6.0 \\
0.0\end{array}$ & $\begin{array}{l}0.0 \\
0.0\end{array}$ & $0.0 \%$ & $\begin{array}{l}32.75 \\
0.46\end{array}$ & $\begin{array}{l}32.05 \\
0.53\end{array}$ & $\begin{array}{l}1.20 \\
0.19\end{array}$ & $100 \%$ \\
\hline S. galilaeus & $\begin{array}{l}\text { Mean } \\
\pm S E\end{array}$ & $\begin{array}{l}12.90 \\
0.11\end{array}$ & $\begin{array}{l}12.90 \\
0.11\end{array}$ & $\begin{array}{l}0.0 \\
0.0\end{array}$ & $0.0 \%$ & $\begin{array}{l}6.0 \\
0.0\end{array}$ & $\begin{array}{l}6.0 \\
0.0\end{array}$ & $\begin{array}{l}0.0 \\
0.0\end{array}$ & $0.0 \%$ & $\begin{array}{l}26.80 \\
0.47\end{array}$ & $\begin{array}{l}25.95 \\
0.51\end{array}$ & $\begin{array}{l}1.43 \\
0.29\end{array}$ & 1005 \\
\hline T. zillil & $\begin{array}{l}\text { Mean } \\
\pm S E\end{array}$ & $\begin{array}{l}13.45 \\
0.13\end{array}$ & $\begin{array}{l}13.45 \\
0.15\end{array}$ & $\begin{array}{l}0.10 \\
0.08\end{array}$ & $\begin{array}{l}6.0 \\
0.0\end{array}$ & $\begin{array}{l}0.0 \\
0.0\end{array}$ & $\begin{array}{l}0.0 \\
0.0\end{array}$ & $\begin{array}{l}0.0 \\
\%\end{array}$ & $\begin{array}{l}14.95 \\
0.35\end{array}$ & $\begin{array}{l}14.95 \\
0.35\end{array}$ & $\begin{array}{l}15.0 \\
0.30\end{array}$ & $\begin{array}{l}0.40 \\
0.17\end{array}$ & 53.30 \\
\hline & $\begin{array}{l}\text { Numbe } \\
* \\
* * \\
* * *\end{array}$ & $\begin{array}{l}\text { of tes } \\
\text { Signi } \\
\text { Signi } \\
\text { Signi }\end{array}$ & $\begin{array}{l}d \text { fishe } \\
\text { cant at } \\
\text { cant at } \\
\text { cant at }\end{array}$ & $\begin{array}{l}=15 \\
3<0 \\
2<0 \\
><0\end{array}$ & & & & $\therefore 8$ & $\begin{array}{l}\text { rechr } \\
\text { Oreod } \\
\text { othe } \\
\text { apia }\end{array}$ & $\begin{array}{l}\text { ois ni } \\
\text { omis } \\
\text { ton g } \\
\text { ii }\end{array}$ & $\begin{array}{l}\text { ictus } \\
\text { letts } \\
\text { laeus }\end{array}$ & & \\
\hline
\end{tabular}




\section{LEGENED OF FIGURES}

Fig. (1): DNA genome from tilapia species. Lane 1 represents $1 \mathrm{~kb}$ DNA marker. Lanes $2-7$ represent DNA of $T$. zillii, $O$. niloticus, O. auraeus. S. galilaeus, $\mathrm{H} 1$ and $\mathrm{H} 2$, respectively.

Fig. (2): Shows the PCR- RFLPs patterns of 18SsrRNA gene of tilapia species. Lane 1 represents $1 \mathrm{~kb}$ DNA marker. Lanes 2 -7 represent gene pattern of $T$. zillii, $O$. niloticus, O. auraeus, $S$. galilaeus, $\mathrm{H} 1$ and $\mathrm{H} 2$, respectively.

Fig. (3): Shows the PCR- RFLPs patterns of 18SsrRNA gene restricted by enzyme EcoRI. Lane 1 represents $1 \mathrm{~kb}$ DNA ladder. Lanes $2-7$ represent gene pattern of $T$. zillii, $O$. niloticus, $O$. auraeus, $S$. galilaeus, $\mathrm{H} 1$ and $\mathrm{H} 2$, respectively.

Fig. (4): Shows the PCR- RFLPs patterns of 18SsrRNA gene restricted by enzyme $B g 1$. Lane 1 represents $1 \mathrm{~kb} D N A$ ladder. Lanes $2-7$ represent gene pattern of $T$. zillii, $O$. niloticus, $O$. auraeus. S. galilaeus, $\mathrm{H} 1$ and $\mathrm{H} 2$, respectively.

Fig. (5): Shows the PCR- RFLPs patterns of 18SsrRNA gene restricted by enzyme Smal. Lane 1 represents $1 \mathrm{~kb}$ DNA ladder. Lanes $2-7$ represent gene pattern of $T$. zillii, $O$. niloticus, $O$. auraets, $S$. galilaeus, $\mathrm{H} 1$ and $\mathrm{H} 2$, respectively.

Fig. (6): Shows the PCR- RFLPs patterns of 18SsrRNA gene restricted by enzyme $A l w N$. Lane 1 represents $1 \mathrm{~kb}$ DNA ladder. Lanes $2-7$ represent gene pattern of $T$. zillii, $O$. niloticus, $O$. auraeus, $S$. galilaeus, $\mathrm{H} 1$ and $\mathrm{H} 2$, respectively.

Fig. (7 ): Shows the PCR- RFLPs patterns of 18SsrRNA gene restricted by enzyme XmaI. Lane 1 represents $1 \mathrm{~kb}$ DNA ladder. Lanes $2-7$ represent gene pattern of $T$. zillii, $O$. niloticus,$O$. auraeus , $S$. galilaeus, $\mathrm{H} 1$ and $\mathrm{H} 2$, respectively.

Fig. ( 8 ): Shows the PCR-RFLPs patterns of 18SsrRNA gene restricted by enzyme Sst II. Lane 1 represents $1 \mathrm{~kb}$ DNA ladder. Lanes $2-7$ represent gene pattern of $T$. zillii, $O$. niloticus, $O$. auraeus, S. galilaeus, $\mathrm{Hl}$ and $\mathrm{H} 2$, respectively. 
Fig. (9): Shows the PCR- RFLPs patterns of 18SsrRNA gene restricted by enzyme Sac II. Lane 1 represents $1 \mathrm{~kb}$ DNA ladder. Lanes $2-7$ represent gene pattern of $T$. zillii, $O$. niloticus, $O$. auraeus. $S$. galilaeus, $\mathrm{H} 1$ and $\mathrm{H} 2$, respectively.

Fig. (10): Shows the PCR- RFLPS patterns of 18SsrRNA gene restricted by enzyme ApaI. Lane 1 represents $1 \mathrm{~kb}$ DNA ladder. Lanes $2-7$ represent gene pattern of $T$. zillii, $O$. niloticus, $O$. auraeus, $S$. galilaeus, $\mathrm{H} 1$ and $\mathrm{H} 2$, respectively.

Fig. (11): Shows the PCR- RFLPs patterns of 18SsrRNA gene restricted by enzyme Aval. Lane 1 represents $1 \mathrm{~kb}$ DNA ladder. Lanes $2-7$ represent gene pattern of $T$. zillii, $O$. niloticus, $O$. auraeus, $S$. galilaeus, $\mathrm{H} 1$ and $\mathrm{H} 2$, respectively. 


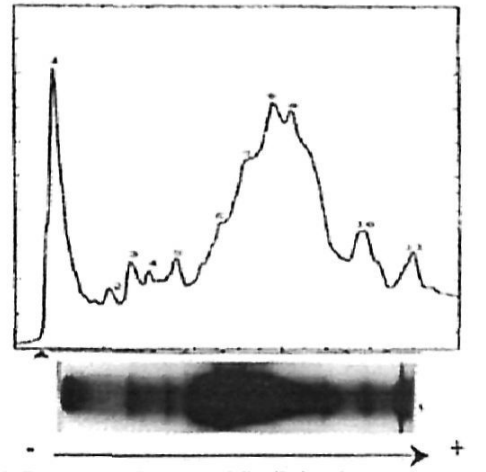

Fig. (1): Plasma proteinogram of 0 . niloticus (untreated samples).

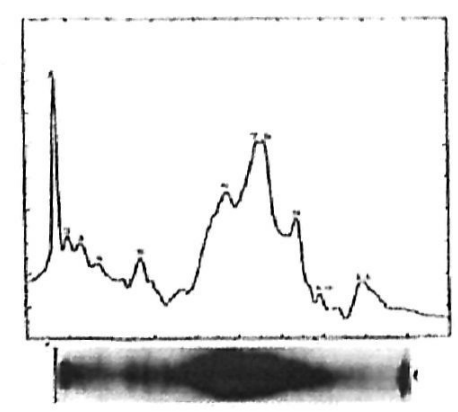

Fig. (3): Plasma proteinograna of $O$, aureus (untreated samples).
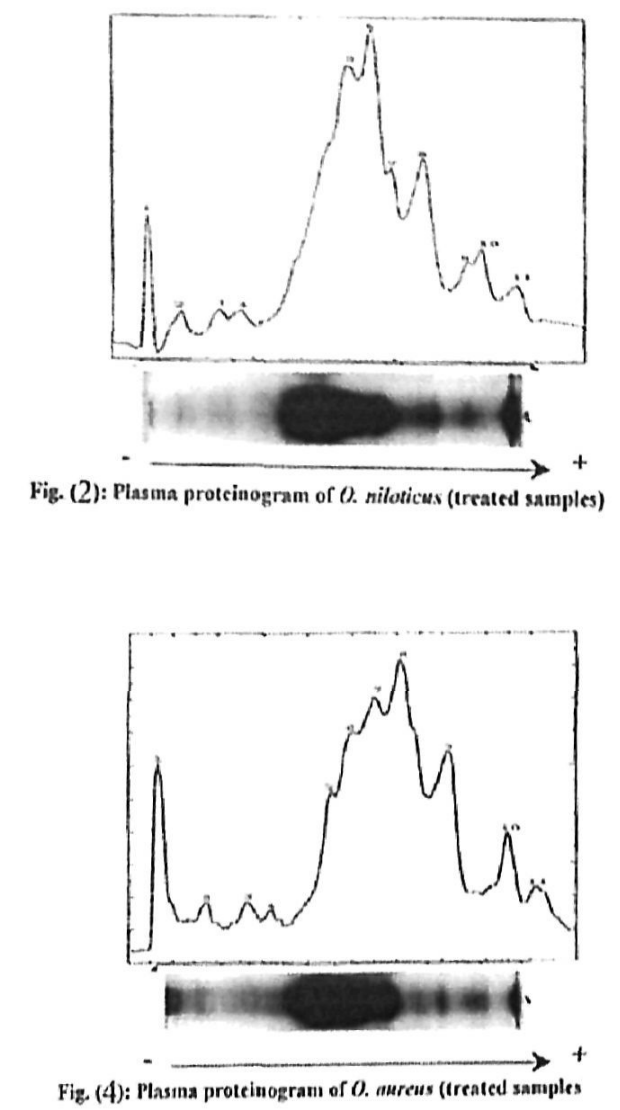

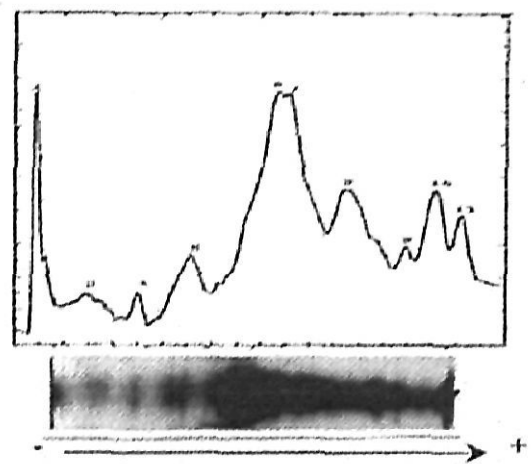

Pig. (5): Plasma proteinogran or $S$ gulijacus (untreated samples).
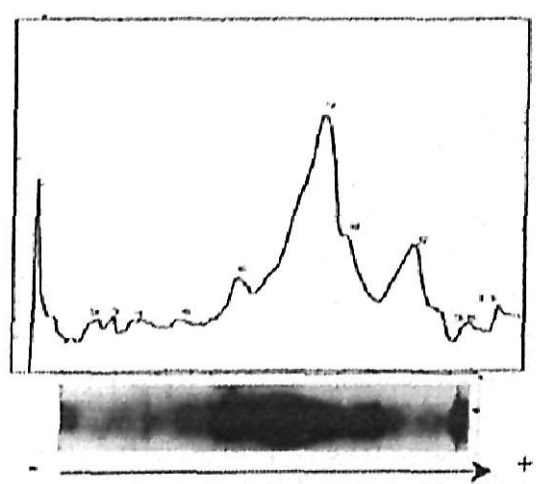

Pig. (7): Plasima proleingrain of T. : Illi (untreated samples)

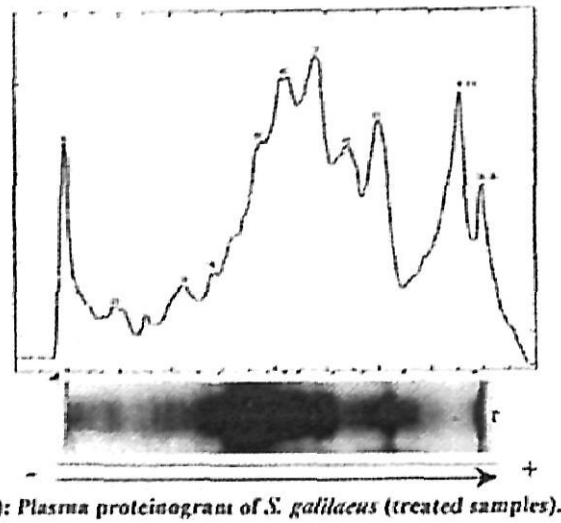

Mig. (6): Pasma protcinograat of S. galilaeus (treated samples).

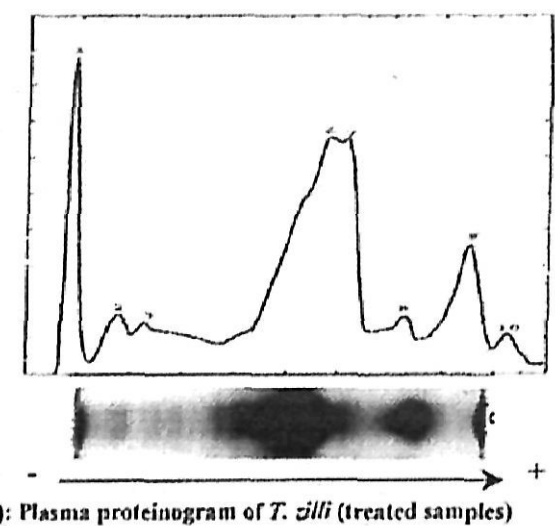

Fig. (8): Plasma proteinogram of T. Eilli (treated samples) 


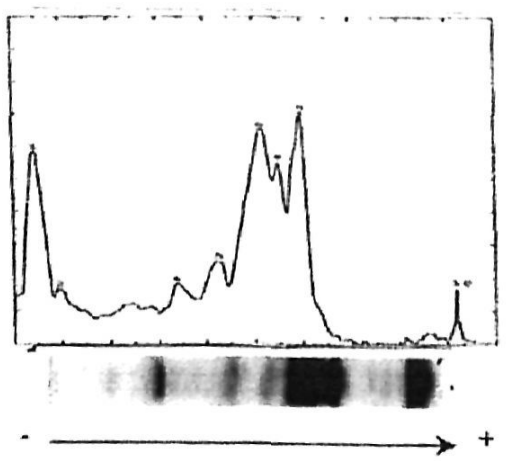

Fig. (9): Muscie proteinograin of $O$. niloticus (untreated samples)

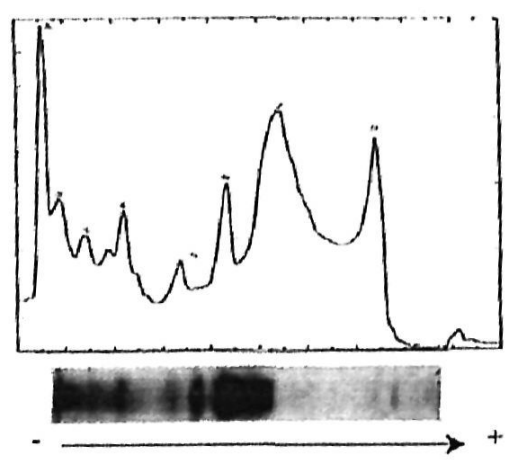

Fig. (1 1): Muscle proteinogram of 0 . aureus (untreated satnples)

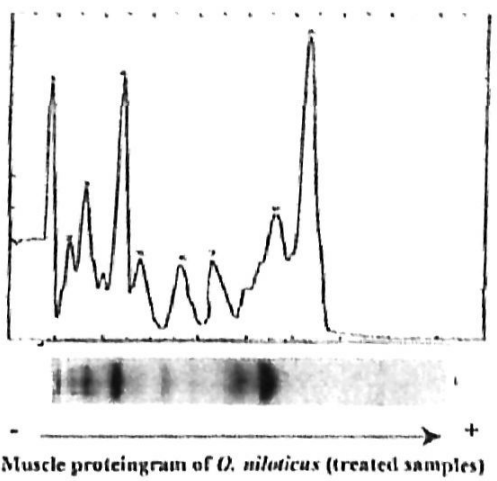

Fig. (I ()): Mtuscle proteingram of 0 . niloticus (treated samples)

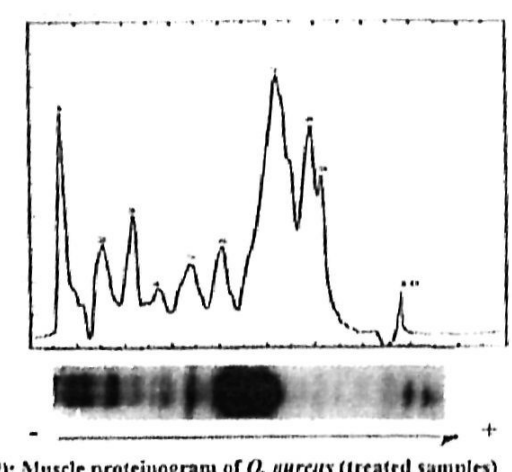

Fig. (1): Muscle proteinogram of O. uuresus (treatrcl samples) 


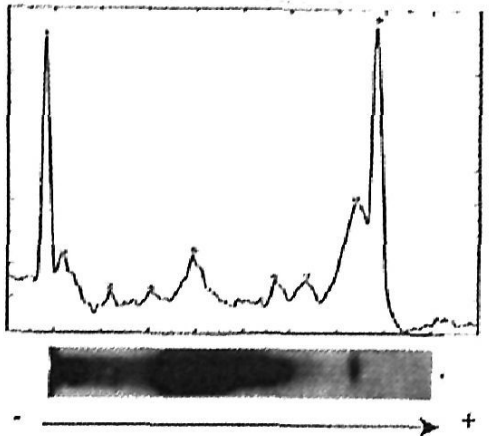

Fig. (13): Muscle proteinogram of S: galilacus (untreated samples)
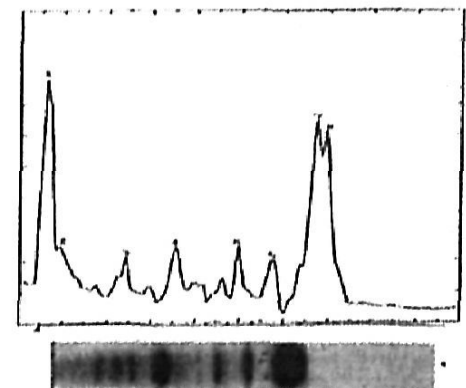

Fig. (15): Muscle proteingram of $T$. Ellit (unlreated samuples)
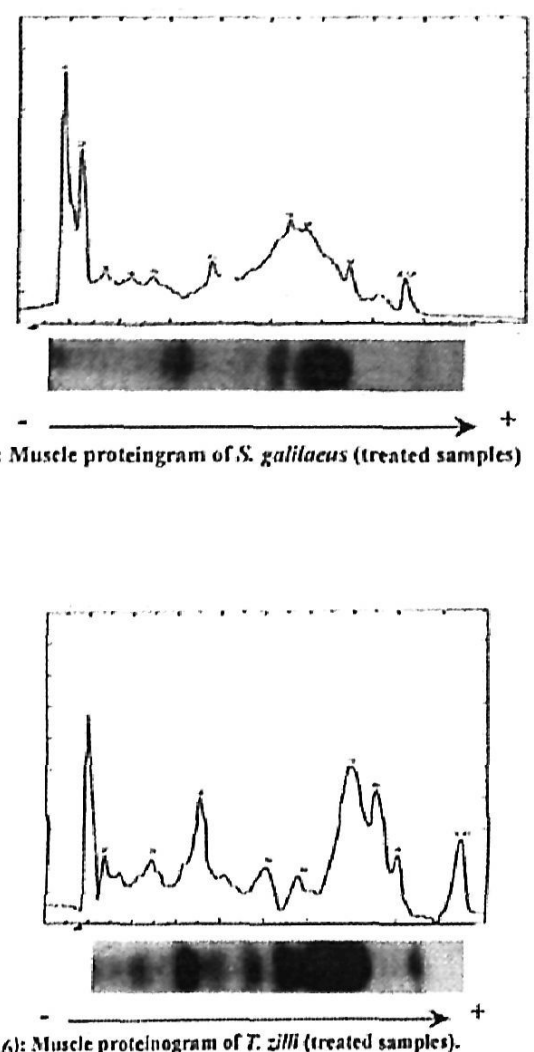